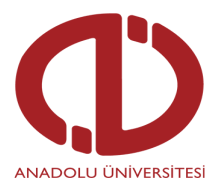

Açıköğretim Uygulamaları ve Araştırmaları Dergisi AUAd

https://dergipark.org.tr/tr/pub/auad



Gönderim: 16.12 .2020

Düzeltme: 07.03.2021

Kabul: 12.04 .2021

Tür: Araştırma Makalesi

\title{
Covid-19 pandemi uzaktan eğitim sürecinde sınıf öğretmenlerinin karşılaştığı sorunlar
}

\author{
Halil SAYGI ${ }^{\mathrm{a}}$ \\ a MEB. Çatalhüyük Munise Lütfi Onat İlkokulu Karatay Konya, ORCID: 0000-0002-9344-3841
}

\begin{abstract}
Özet
$\mathrm{Bu}$ çalışma tüm dünyayı etkisi altına alan ve henüz tedavisi bulunamamış covid-19 virüsünün sebep olduğu pandemi nedeniyle uzaktan eğitim faaliyetlerinde sınıf öğretmenlerinin karşılaştı̆̆ sorunların tespit edilmesi ve bunlara çözüm önerileri sunmayı amaçlamaktadır. Çalışmanın evreni Karatay ilçesinde görev yapan sınıf öğretmenleri oluştururken, araştırmanın örneklemini basit tesadüfi örnekleme yöntemiyle belirlenen halen görev başında olan 40 sınıf öğretmeni oluşturmaktadır. Basit tesadüfi örnekleme yönteminde kendisine, okul idareleri ve uzaktan elektronik anket formları aracılığıyla ulaşılabilen sınıf öğretmenlerinin görüşlerine başvurulmuştur. Basit tesadüfi örneklemede evren içinden rastgele birimler listelenir ve seçilir (Kılıç, 2013, s. 45). Araştırma problemi belirlendikten sonra literatür taraması yapılmış, uzaktan eğitim kavramı irdelenmiş, Dünya'da ve Türkiye'de uzaktan eğitim durumları değerlendirilmiş, covid-19 salgınının ortaya çıkışı ve hastalık seyrinde dünya devletlerinin uyguladığı eğitim politikaları ve ülkemizin attığı eğitim adımları irdelenmeye çalışılmıştır. Alan yazın taramasının ardından uzaktan eğitim kapsamında karşılaşılabilecek sorunları içeren anket formu geliştirilerek Karatay ilçesinde görev yapan sınıf öğretmenlerinin değerlendirmeleri istenmiştir. Araştırma sonunda görev yapılan ilkokulların teknolojik açıdan yetersiz olduğu, öğrencilerin uzaktan eğitime devamlarının yeterli olmadığı, meslektaş iletişıminin iyi olduğu, ögretmenlerin ölçme ve değerlendirme uygulamalarında zorlandıkları bulguları çerçevesinde veriler analiz edilerek araştırmanın sonuç ve öneriler kısmında tavsiyelerde bulunulmuştur. Fatih Projesi Faz III uygulamasının ilkokullara uygulanması, uzaktan eğitim devam zorunluluğunun getirilmesi, öğrencilerin teknolojik olarak desteklenmesi ile ölçme ve değerlendirme uygulamalarının uzaktan eğitime uyarlanması önerilerinde bulunulmuştur.
\end{abstract}

Anahtar Sözcükler: Covid-19 Pandemisi, Uzaktan Eğitim, Sınıf Öğretmeni.

\section{Problems encountered by classroom teachers in the covid-19 pandemic distance education process}

\begin{abstract}
This study aims to identify the problems faced by classroom teachers in distance education activities due to the pandemic caused by the covid-19 virus, which has affected the whole world and has not yet been found, and to offer solutions to them. While the population of the study is the classroom teachers working in the district of Karatay, the sample of the study consists of 40 classroom teachers who are currently on duty determined by simple random sampling method. In the simple random sampling method, opinions of classroom teachers, who can be reached by school administrations and remote electronic questionnaires, were consulted. In simple random sampling, random units from the universe are listed and selected (Kıliç, 2013, p. 45). literature made after research problem is identified, have been analyzed in the concept of distance learning, distance education in Turkey and the world situation were evaluated, covid-19 The emergence of the epidemic and educational policies implemented by the world's governments in the course of the disease and training steps taken by our country has been studied. After the literature review, a questionnaire containing the problems that may be encountered within the scope of distance education was developed and the classroom teachers working in the district of Karatay were asked to evaluate. At the end of the study, the data were analyzed within the framework of the findings that the primary schools worked in were technologically inadequate, students' attendance to distance education was not sufficient, colleagues had good communication with colleagues, and teachers had difficulties in assessment and evaluation practices, and recommendations were made in the results and recommendations of the study. It has been suggested that the Fatih Project Phase III application should be applied to primary
\end{abstract}

Kaynak Gösterme

Sayg1, H. (2021). Covid-19 pandemi uzaktan eğitim sürecinde sınıf öğretmenlerinin karş1laştığı sorunlar. Açıöğretim Uygulamaları ve Araştırmalart Dergisi (AUAd), 7(2), 109-129. https://doi.org/10.51948/auad.841632 
schools, the obligation to continue distance education, support students technologically, and adaptation of measurement and evaluation practices to distance education.

Keywords: Covid-19 Pandemic, Distance Learning, Classroom Teacher

\section{Giriş}

Uzaktan eğitim; 2020 yılında Çin'de başlayan, tüm insanlığın yaşadığı ve önlenemez salgın hastalık nedeniyle çok daha önemli hale gelmiş̧ir. İnsanların hastalık bulaş riskinden dolayı birbirlerine sosyal mesafe ile yakınlaşmaktan kaçındığı bir ortamda insanlı̆̆ın en temel gereksinimlerinden olan eğitim ve öğretim ihtiyacının teknolojik araçların da yardımıyla uzaktan eğitimle giderilmesi zorunluluğu oluşmuştur. Çin'in Hubei eyaletinde 2019 yılının Aralık ayı sonunda nefes darlı̆ı̆, ateş, eklem ağrıları, halsizlik gibi belirtilerle baş gösteren, zatürreye dönüşerek tedavisi bulunamayan ve insanlığ ciddi manada tehdit eden salgın hastalık tüm dünyaya yayılarak WHO (Dünya Sağlık Örgütü) tarafından 11 Mart 2020 tarihi itibariyle pandemi olarak ilan edilmiştir (http-1). Dünya'da yaşanan bu gelişmeler ile birlikte pek çok ülke salgınla mücadele kapsamında kısıtlamalar uygulamaya başlamış, eğitim öğretim faaliyetlerinin yürütüldüğü okullar da bundan nasibini almıştır. Pek çok ülke; okulları tatil etmiş ve sonrasında eğitim öğretime uzaktan eğitim ile devam etmiştir. Türkiye'de ilk vakaların görülmeye başlanması üzerine Milli Eğitim Bakanlığı tarafından mart ayı ara tatili bir hafta uzatılarak 23 Mart 2020 tarihinden itibaren uzaktan eğitime geçileceği açıklanmıştır (http-2).

\section{Dünyada ve Türkiye'de Uzaktan Eğitim Uygulamaları}

Literatür tarandığında uzaktan eğitimin ilk olarak İsveç'te 1728 yılında Boston Gazetesi'nde mektupla ders verileceği ilanları ile ortaya çıktığı değerlendirilmektedir (Özbay, 2015, s. 378). Dünyada uzaktan eğitim faaliyetlerinin gelişimi incelendiğinde mektupla, radyo yayınları ile, televizyon aracıllğı ile ve web tabanlı çevrimiçi internet araçları ile yapıldığı görülmektedir. Eğitsel ilk radyo yayınının Amerika'da yapıldığı görülür (Akyürek, 2020, s. 5). Uzun yıllar çeşitli yöntemlerle uygulanan uzaktan eğitim 1980' li yıllardan itibaren önlenemez bir gelişme göstermiştir (Akyürek, 2020, s. 5). Günümüzde her ne kadar teknoloji ilerlemiş olsa da uzaktan eğitim çalışmalarının büyük çoğunluğunun yüksek öğretimde odaklanmış olduğu görülmektedir. Uzaktan eğitimin mektupla başladığı yapılan bir çok araştırmada ortaya konulmaktadır. 1800' lü yıllarda Amerika, İsveç, Almanya, Fransa, Rusya gibi ülkelerde mektupla uzaktan eğitim faaliyetlerinin yürütüldüğü anlaşılmaktadır (Kırık, 2014, s. 80). 1980' li yıllardan itibaren televizyonlar aracilı̆̆ ile uzaktan eğitim 
faaliyetlerine geçilmiştir. 1990'lı yıllardan itibaren kablolu internet yayınları başlayarak uzaktan eğitim yeni bir boyut kazanmıştır.

Türkiye'de uzaktan eğitimin tarihçesi 1924 y1lına kadar gitmekte, uzaktan eğitim terimine ilk olarak John Dewey’ in öğretmen eğitim raporunda rastlanmaktadır (Başaran vd., 2020, s. 370). Dünyada 1728 yılında Amerika'da gazete haberlerinde mektupla öğretim olarak başlayan uzaktan eğitim süreci ülkemizde 70-80 y1l gibi bir geçmişe sahiptir. Bozkurt (2017, s. 87-88); Türkiye'de uzaktan eğitimi dört dönemde ele almaktadır: 1- Kavramsal, 2Mektupla, 3- Radyo ve Televizyon, 4- İnternet Tabanlı. Ülkemizde 1950'li yıllarda banka memurlarının uzaktan mektupla öğretimleri amaçlanmış, MEB atmışlarda mektupla öğretime geçmiştir. 1975 yılında üniversiteye gidemeyen öğrenciler için YAYKUR faaliyetlerine başlamıştır (Gökçe, 2008, s. 3). 1982 yılından itibaren Anadolu Üniversitesi uzaktan eğitim çalışmalarına geçiş yapmıştır (Karatepe vd., 2020, s. 1263). Günümüzde Anadolu Üniversitesi, İstanbul Ünv. ve bazı üniversiteler UZEM' ler aracılığı ile uzaktan eğitim yapılmaktadır (Keskin ve Kaya, 2020, s. 60). 2011-2012 eğitim öğretim yılından itibaren FATİH Projesi'nin hayata geçmesi ile dijital içeriklerin üretilmesi ve bu platformda kullanıma sunulmak üzere MEB tarafından EBA kurulmuştur (http-4). Türkiye'de uzaktan eğitim çalışmaları örgün eğitimin dışında kalmış bireyler için MEB Hayat Boyu Öğrenme Genel Müdürlüğü bünyesinde oluşturulan açık öğretim ortaokulu ve açık öğretim liseleri tarafından da yürütülmektedir. 1992 senesinde açı öğretim lisesi, 1998 yılında ise ilköğretim ikinci kademe öğrencileri için açık öğretim ilköğretim okulları faaliyete başlamıştır. MEB tarafından EBA alt yapısı ile öğretmenlerin hayatları boyunca öğrenme ortamları sağlayabilmek için UZEM kurulmuştur (Özbay, 2015, s. 387).

\section{Covid-19 Salgını ve Salgının Dünya'da Seyri}

Covid-19; yeni tip korona virüs olarak da adlandırılan SARS-COV-2 virüsünün neden olduğu hastalık türüdür. Dünya Sağlık Örgütü (WHO) bu virüsle ilk defa Aralık 2019 ayının sonunda Çin Halk Cumhuriyeti'ndeki "'viral pnömoni” raporlarıyla haberdar olmuştur. Korona virüs ailesi tabiatta bulunan ve hastalığa sebep olan geniş bir virüs ailesidir. Korona virüslere yarasa, yılan, kaplumbağa, pangolin gibi vahşi hayvanların doğal veya ara konak olabilecekleri yayınlanan araştırmalarda geçmektedir (Dikmen vd., 2020, s. 30). Yeni tip korona virüsün sebep olduğu hastalık her insanda aynı etkiyi yapmamaktadır. Faklı kişilerde farklı belirtiler ve etkiler göstermektedir. Virüse enfekte olan kişilerde en yaygın bulgular kuru öksürük, halsizlik ve yüksek ateştir. Daha az belirtileri ise ishal, boğaz ağrısı, tat ve 
koku kaybı, baş ağrısı şeklindedir. Tehlikeli bulgular ve tıbbi yardım almayı gerektirenler ise nefes almada güçlük, konuşmada zorlanma, göğüs baskısıdır (http-6).

Günümüzde bilinmektedir ki; korona virüs damlacık yolu ve hasta olan kişilerin nefes veya öksürük ile etrafa yaydıkları damlacıklarına temas edilmesi, solunması ile insandan insana bulaşmaktadır (Dikmen vd., 2020, s. 30-31). Henüz kesin bir tedavisi olmayan covid-19 hastalığına çareler aranmakta, yapılan aşı çalışmalarının olumlu olarak sonuçlanması tüm dünyada umutla beklenmektedir.

İnsanlık 2019 Aralık ayının sonunda Çin'in Hubei eyaletinin Wuhan şehrinde baş gösteren korona virüs hastalığının pençesine düşmüştür. Tedavi edilemeyen ve tüm yaş gruplarında nefes darlığı,yüksek ateş, öksürük, eklem ağrıları gibi belirtilerle ortaya çıkan ve 14 gün kuluçka süresi bulunan korona virüs kısa zaman içerisinde tüm dünyaya yayılmıştır (http-5). Covid-19 güçlü bulaşıcılığı ile farkına varılması güç, süratle yayılım gösteren tehlikeli bir tür hastalıktır (Yılmaz vd., 2020, s. 3). Çin'den başka korona virüs tespit edilen ilk ülke Tayland olarak kayıtlara geçmiştir. Korona virüsün 11 Mart 2020 tarihinde Sağlık Bakanlığ tarafından Türkiye'de tespit edildiği açıklanarak virüsün Türkiye'ye girmiş olduğu resmi kaynaklardan ifade edilmiştir (http-3).

WHO istatistiklerine göre ilk başlangıç yeri Çin olan korona virüsün merkezi ilk etapta İtalya olurken, Aralık 2020 itibari ile Amerika kıtası olduğu anlaşılmaktadır. Salgın ile mücadele kapsamında bilim insanlarının önerileri çerçevesinde ülkeler sokağa çıkma kısıtlaması, eğitim öğretimin uzaktan yapılması, alış veriş merkezlerinin kapatılması, kafe ve restoranların faaliyetlerini durdurması, toplu taşımada bazı kısıtlayıcı tedbirleri hayata geçirmektedirler.

Korona virüsün sebep olduğu hastalık yakın zamanda ortaya çıktığından bilinen pek fazla bilgi olamamakla birlikte literatürü de henüz yenidir. İlk başlangıcı grip gibi belirtilerle başlayan hastalığın 3-5 gün kuluçka süresi bulunurken bu süre 14 güne kadar çıkabilmektedir. İnsanlık bu hastalığı yeni tanımakta ve hastalığın sağlık, ekonomi, turizm, eğitim, ulaşım gibi birçok alanda uğrattığı yıkımlara çareler aramaktadır. Tüm dünyada olduğu gibi Türkiye'de korona virüsün yol açtığı hastalığı önlemek, yayılımını durdurmak maksadıyla bazı tedbirler alınmaktadır. Halen önlenemez yayılımı devam eden covid-19 önlemleri çerçevesinde; havalimanlarının kapatılması, uluslararası yolculukların durdurulması, havalimanları, garlar, alışveriş merkezlerine girişlerde HES (Hayat Eve Sığar) kodu sorgulaması ve ateş ölçümlerinin yapılması, restoranlarda "'Gel-Al” uygulamasının hayata geçirilerek müşteri kabulünün durdurulması, 65 yaş üstü vatandaşların ve 20 yaş altı gençlerin günün belli saatlerinde sokağa çıkmalarının kısıtlanması, tüm ülkede sokağa çıkma kısıtlamaların uygulanması, belli sokak ve caddelerde toplu halde bulunulmaması, maske takılması, açı 
alanlarda sigara içilmemesi gibi belli başlı tedbirler bilim insanlarının tavsiyeleri ile ülke yöneticileri tarafından uygulanmaktadır.

\section{Covid-19 salgın sürecinde Dünya'da eğitim}

Hastalık sebebiyle dünya genelinde pek çok ülkede sağlık sektöründen sonra eğitim sektörü de etkilenmiştir. Pek çok ülkede okullar; ya tatil edilmiş veya uzaktan eğitim faaliyetlerine geçmiştir. Korona virüs salgını sebebiyle dünyadaki yükseköğretim kurumlarının geneli uzaktan eğitim faaliyeti içerisine girmiştir ( Sarı, 2020, s. 124). Ancak ülkelerin ekonomik ve gelişmişlik durumları öğrencilerin uzaktan eğitime erişim konusunda belirgin farklılıklar ortaya çıkarmıştır. Pek çok ülke internet altyapısı kullanarak farklı uygulamalar ortaya koyarken; bazı ülkeler de televizyon programları aracılığıyla uzaktan eğitim faaliyetlerine devam etmiştir (Yılmaz vd., 2020, s. 5-6). Covid-19 salgını nedeniyle UNESCO tarafından yapılan araştırmalarda süreç içinde seksen dört ülkenden elli sekizinin sınavları ertelediği veya tekrar yapılandırıldığı tespit edilmiştir (Can, 2020, s. 12). Birkaç dünya ülkesinin pandemi döneminde uygulamaya aldığı eğitim politikaları aşağıda özetlenmiştir: Çin; 270 milyondan fazla öğrencisi bulunan ülkede okullar kapanmış ve online bir eğitim platformlarında uzaktan eğitime devam edilmiştir. Ücretsiz ilk-ortaokul öğrencileri için öğrenme firsatları oluşturulmuştur (Yılmaz vd., 2020, s. 7). Amerika; pandeminin başlamasıyla birlikte eğitim öğretim faaliyetlerini online ortamlara taşıyan ilk üniversitelerden biri Washington üniversitesi yaklaşık elli bin öğrencisine uzaktan eğitim imkanı sunmuştur. Uluslararası öğrenci kayıtlarının ne kadar zarar göreceği halen belirsizliğini sürdürmektedir (Yamamoto ve Altun, 2020, s.27-28). İngiltere; salgın başlangıcında sürü bağışıklığı ilkesini benimseyen ülkede yüksek öğretimin pandemiden etkilenmeyeceği düşünülmüştür. Ancak durumun ciddiyeti belirginleştikten sonra eğitimin sekteye uğramaması için çözümün uzaktan eğitimde olduğu anlaşılmıştır. Fransa; 'sınıfım evde" uygulaması ile sanal sınıflar oluşturarak uzaktan eğitim faaliyetlerine geçmiştir (Yılmaz vd., 2020, s. 8). Korona virüsün sebep olduğu sonuçlar değerlendirildiğinde tüm dünyayı etkileyen bir sağlık hastalığın ötesinde insanlık ve eğitimin aşması gereken büyük bir engel olduğu anlaşılmaktadır (Bozkurt, 2020, s. 129). Süreç sonunda edinilen tecrübenin; yüz yüze eğitime geçildiğinde eğitime yön vereceği ve ilham kaynağı olacağ değerlendirilmektedir (Yıldırım, 2020, s. 10). Süreç içerisinde dünyada Google Meet, Google Hangoust, Zoom, Cisko Webex gibi çevrimiçi eğitim uygulamaları önemli bir yer edinmiştir (Yamamoto ve Altun, 2020, s. 32). 


\section{Covid-19 salgın sürecinde Türkiye'de eğitim}

İlk olarak 11 Mart 2020 tarihi akşam saatlerinde ülkemizde korona virüs vakalarının tespit edildiği Sağlık Bakanlığı tarafından açıklanmıştır. Bunun üzerine ülkemizde oluşturulan bilim kurulu tavsiyeleri doğrultusunda 16 Mart 2020 den itibaren Milli Eğitim Bakanlığı tarafından okullar tatil edilmiştir. Milli Eğitim Bakanlığı tarafından 23 Mart 2020 Pazartesi gününden itibaren uzaktan eğitime EBA canlı ders uygulamaları ve TRT EBA TV aracılığı ile başlanacağı açıklanmıştır (http-2). Milli Eğitim Bakanlığı korona virüsün sebep olduğu salgın hastalık nedeniyle toplumun eğitim ihtiyacını karşılamak ve sekteye uğramamasını sağlamak üzere TRT ile işbirliğine gitmiş EBA alt yapısını güçlendirmeye gayret etmiştir (Özer, 2020, s. 1124). TRT EBA İlkokul, TRT EBA Ortaokul ve TRT EBA Lise olmak üzere 23 Mart 2020 tarihinden itibaren üç kanal yayınlarına başlamıştır (Başaran vd., 2020, s. 371). Yükseköğretim Kurulu, salgın dolayısı ile bahar dönemi derslerinin uzaktan eğitim yoluyla devam edeceğini 26 Mart 2020 tarihinden itibaren yüz yüze eğitime ara verdiklerini duyurmuştur (Yılmaz vd., 2020, s. 11). MEB tarafından 23 Mart-30 Nisan tarihleri arasında uzaktan eğitimin yürütüleceği duyurulmuş, ancak daha sonra uzaktan eğitimin 31 Mayıs 2020 tarihine kadar devam edeceği ilan edilmiştir ( Can, 2020, s. 14-15). Ancak 18 Mayıs 2020 tarihli kabine toplantısında 2019-2020 eğitim öğretim döneminin sonlandırılması kararı alınmıştır (http-8). Milli Eğitim bakanlığı TEGM tarafından Okulöncesi ve İlköğretim Kurumları Yönetmeliği'nde pandemi nedeniyle yaşanan olağan üstü durumla ilgili olarak eğitim öğretime ara verilmesi, öğrenci başarılarının değerlendirilmesi ve telafi programları hakkında değişikliğe gidilmiştir (http-13). Milli Eğitim Bakanlığı, Türk Standartları Enstitüsü işbirliği ile eğitim kurumlarında sürdürülebilir hijyen şartlarını sağlamak ve hastalığın okul kaynaklı yayılımını ortadan kaldırmak amacıyla '’Eğitim Kurumlarında Hijyen Şartlarının Geliştirilmesi ve Enfeksiyonu Önleme Kontrol Kılavuzu" nu 28 Temmuz 2020 tarihi itibari ile yayınlamıştır. Bu kılavuz kapsamında okullarda sürdürülebilir hijyen koşullarının sağlanabilmesi amacıyla ''Okulum Temiz Belgesi" ile belgelendirilmesi şartı aranmıştır (http-9). Ülke genelindeki okullar gerekli masa başı, saha ve bilgilendirme çalışmalarını yaparak bu belgeyi almak için müracaatta bulunmuşlardır. Milli Eğitim Bakanlığı salgın sürecinde eğitim paydaşlarının veli, öğretmen okul yöneticisi ve öğrencilerin nasıl davranması gerektiği ile ilgili rehberlik amacıyla 2020 Ağustos ayı itibari ile bilgilendirme metinleri yayınlamıştır (http-7). MEB, yüz yüze eğitime

anasınıfı ve 1.sınıf öğrencilerinden başlanmak üzere kademeli olarak 21 Eylül 2020 tarihinden itibaren geçileceğini duyurdu (http-10). Yapılan açıklamaya göre eğitim öğretim yılı uyum programı kapsamında sınıf öğrencileri gruplara ayrılıp seyreltilmiş olarak haftada 
bir gün 21-25 Eylül tarihlerinde okula devam etmeleri, 28-Eylül -2 Ekim tarihleri arasında da 30 dakikalık beş etkinlik saatinden oluşacak program kapsamında haftada iki gün okula gelmeleri kararlaştırılmıştır. Kademeli ve seyreltilmiş programlarla yüz yüze eğitime geçilen eğitim ortamlarında, veliler okullara alınmamış, kalabalık oluşturmayacak şekilde sınıf mevcutları azaltılmış, okul girişlerinde HES kodu sorgulaması, hem personel hem de ziyaretçiler için uygulamaya geçirilmiştir. Öğrencilerin ve öğretmenlerin HES kodları toplu halde sorgulanarak risk grubundakilerin okula girmeleri önlenmeye çalışılmıştır. Daha sonra yapılan açıklamada okullarda yüz yüze eğitimin ikinci aşaması olarak ilkokul 2. 3. ve 4. sınıfların da 12 Ekim 2020 tarihinden itibaren kademeli olarak haftada iki gün okullara yüz yüze devam etmesi kararı duyurulmuştur (http-11; http-14). Ancak korona virüsün sebep olduğu salgın hastalığın dünya ve Türkiye'deki seyri dikkate alınarak 17 Kasım 2020 tarihinden itibaren kabine toplantısında okulların 4 Ocak 2021 tarihine yüz yüze eğitime ara verilerek uzaktan eğitim yapılacağı MEB tarafından ilan edilmiştir (http-12). Türkiye alt yapısı önceden oluşturulmuş EBA ve TRT işbirliği ile oluşturulan TRT EBA İlkokul, TRT EBA Ortaokul ve TRT EBA Lise televizyon kanallarından salgın süreci eğitim faaliyetlerini yönetmeye devam etmektedir. 21-25 Eylül 2020 tarihleri arasında TRT EBA İlkokul kanalından yayınlanan ilkokul ders programı Şekil 1 'de gösterilmiştir.

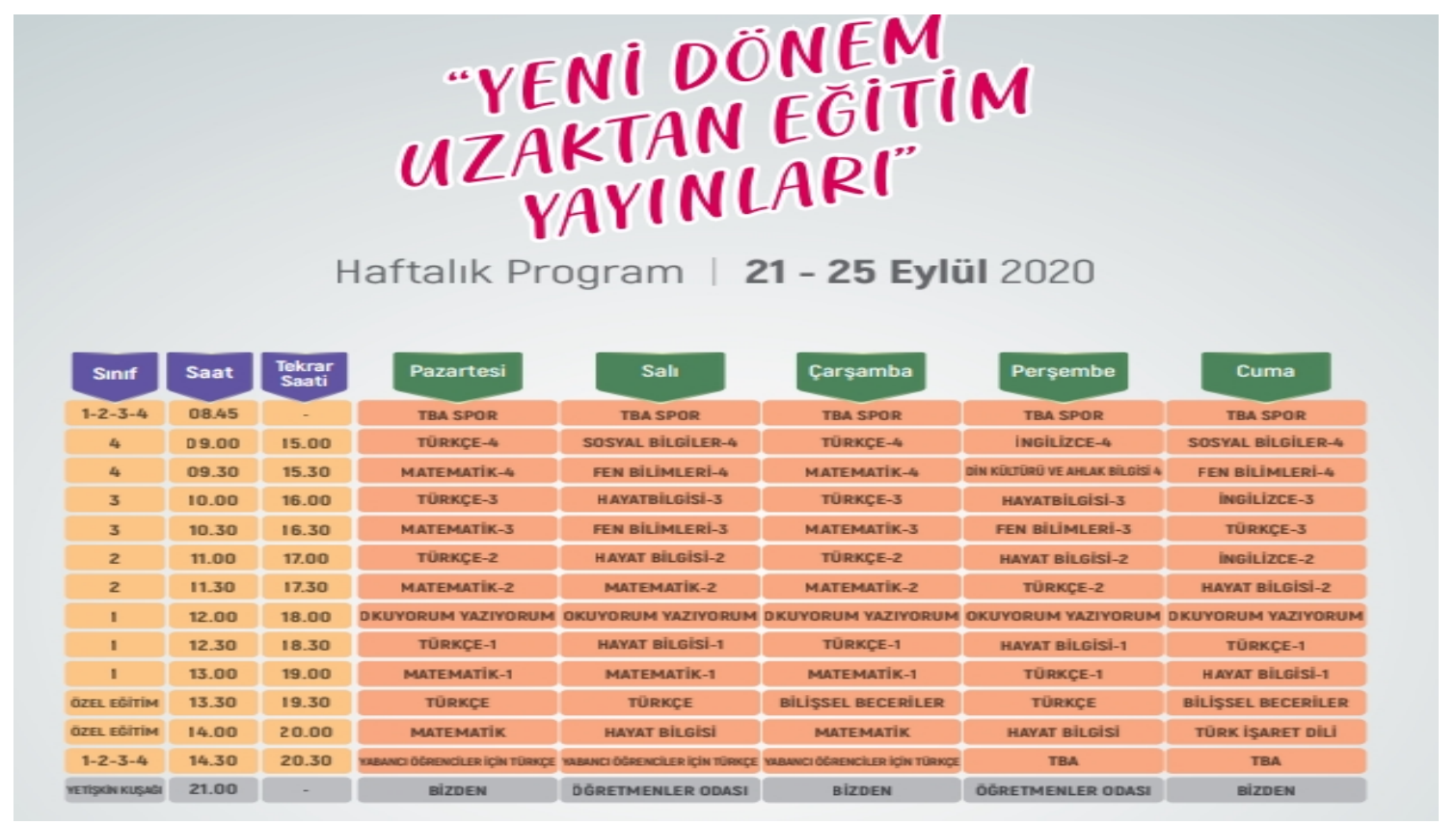

Şekil 1. TRT EBA İlkokul 21-25 Eylül 2020 Haftalık Ders Programı (http-15) 
Yaşanan tüm bu zorlu süreç içerinde bu çalışmada zorunlu uzaktan eğitim kapsamında sınıf öğretmenlerinin karşılaştığı sorunlar irdelenmeye çalışılarak bu sorunlara çözüm önerileri sunulmaya çalışılacaktır.

\section{Araştırma Sorunsalı}

Covid-19 pandemi süreci uzaktan eğitim faaliyetleri ile ilgili çok sayıda araştırma yapıldığı literatür taramasından anlaşılmaktadır. Gelişen ve değişen dünyada teknolojik yeniliklerden eğitim de kendine düşen payı almaktadır. Gelişim tarihi iki asırlık bir zamanla sınırlı olsa da uzaktan eğitim dünya genelinde teknolojik gelişmelere bağlı olarak baş döndürücü bir gelişme göstermiştir.

Uzaktan eğitim; farklı ortamlardaki kaynak ve alıcı arasında çeşitli iletişim araçları ile sistematik bir şekilde gerçekleşen öğretim yöntemi, eğitim teknolojisi uygulamasıdır (Uşun, 2006, s. 7). Son yıllarda e-learning kavramı ile de özdeşleşmiştir. Herand ve Hatipoğlu'na (2014, s. 67) göre e-learning; değişik ortamlardaki öğretmen, öğrenci ve eğitim materyallerinin bir arada bulunmadan çeşitli iletişim araçları ile meydana getirilen eğitim etkinliğidir. Koçer'e (2001, s. 7) göre uzaktan eğitim eğitici ile öğrencinin aynı yerde olmadan gerçekleştirdiği eğitim faaliyetidir. Uzaktan eğitim; öğretme-öğrenme olgularını birleştiren bir kavramdır (Kaya, 2002, s. 11). Uzaktan eğitim Gökçe’ye (2008, s. 2) göre yer ve zamandan bağımsız olarak gerçekleştirilebilen etkili ve ekonomik bir eğitim yöntemidir. Uzaktan eğitim senkron ve asenkron olmak üzere iki şekilde yapılmaktadır. Senkron şekilde yapılan uzaktan eğitimde kaynak ve alıcı çeşitli iletişim ve teknolojik araçlarla aynı zaman diliminde karşılıklı ve etkileşimli halde eğitim gerçekleştirirler. Asenkron şeklinde yapılan uzaktan eğitimde zamandan bağımsız olarak web tabanlı olarak öğrenci istediği zaman diliminde eğitim faaliyetlerine katılabilir. Canbek (2015, s. 103) uzaktan eğitimin dört bileşeninden bahseder. Bunlar; kurumsal taban, öğreticilerin zamansal ve mekansal uzaklığı, karşılıklı iletişsim, öğrenen-kaynak ve öğretici bağlantıda olmasıdır. Tanımlardan da anlaşılacağı gibi eşzamanlı ve eşzamansız olarak gerçekleştirilen uzaktan eğitim; farklı mekanlarda öğreten ve öğrenenin çeşitli eğitim teknolojilerini kullanarak karşılıklı olarak gerçekleştirdikleri eğitim faaliyetleridir.

Araştırmacılar uzaktan eğitim uygulamalarının faydalarından bahsetmektedir. Balaban (2012, s. 3), bunları az zaman, ekonomiklik, daha fazla kişiye erişim, bilginin daha çok yayılması, fazla memnuniyet, eğitim fırsatının artması şeklinde sıralamaktadır. Ağır (2007, s. 6), uzaktan eğitimin başlıca faydalarını aşağıdaki şekilde ifade etmektedir. Uzaktan eğitim; öğrenenin mekandan bağımsız olarak eğitime katılmasını sağlar, ekonomiktir, maliyet düşer, bilgiye erişmek ve yaymak kolaydır, hayat boyu öğrenme gerçekleşebilir, daha çok kitlelere 
ulaşılabilir, her yaştaki her bireye eğitim hakkı tanır. Akyürek' e (2020, s. 4) göre uzaktan eğitimin yararları: firsat eşitliği, kitle öğretiminin sağlanması, zengin materyal imkanı, öğrenmede bireysellik, sınıf ortamına mecbur kalmamak şeklinde sıralamaktadır. Kaya (2002, s. 19-20)' ya göre uzaktan eğitimin bazı faydalar sağladığı değerlendirilmektedir. Bunlar; farklı eğitim tercihi sunma, firsat eşitliği sağlama, maliyeti indirme, serbestlik sunma, zengin içerik sunma, nitelik yükseltme, bireysel çalışma ve öğrenme, öğrenciye sorumluluk verme vb. olarak ifade edilmektedir.

Uzaktan eğitimin faydalarının yanında bazı sınırlılıkları da mevcuttur. Ağır (2007, s. 7) bu sınırlılıkları öğrencilerde sosyalleşmenin engellendiği, tam öğrenmenin gerçekleşemeyeceği, daha çok ders hazırlığının öğretenin emek kaybına yol açtığı, kalabalık öğrenci gruplarında iletişim sınırlılığı şeklinde ifade etmektedir. Akyürek (2020, s. 4) uzaktan eğitimin yararlarının yanında sınırlılıklarından da bahsetmektedir. Bunlar; yüz yüze öğrenci ilişkilerini kolaylaştırmaması, sosyalleşmenin önünde engel olması, öğrenme alışkanlığı olmayan bireylerde sorun yaşanması, çalışan bireylerin dinlenme vaktini alma, beceri veya uygulamaya dönük derslerde yetersiz kalınması gibi.

Kaya (2002, s. 20)' ye göre uzaktan eğitimin belli başlı sınırlılıkları da vardır. Bunları özetle ifade etmek gerekirse; bireylerin sosyalleşmesinin önünde engel olması, öğrenenöğreten yüz yüze ilişkilerinin zorlaşması, öğrenen bireylerin dinlenme vakitlerinin alınması, uygulama derslerinde verim alınamaması, kendi kendine öğrenemeyen bireylerin zorluk yaşaması vb. olarak sıralanabilir.

Kantos'un (2020) yaptığı araştırmada uzaktan eğitimi mi, yüz yüze eğitimi tercih edersiniz şeklinde ilkokul birinci kademe öğretmenlerinin görüşlerine başvurulduğu anlaşılmaktadır. İncelenen bu araştırmada ilkokul öğrencilerine uzaktan eğitimin uygun olmadığı, internet ve teknolojik alt yapısı eksik olan öğrencilerle iletişimde güçlükler yaşandığı gibi bir takım sonuçlara ulaşıldığı değerlendirilmektedir (Kantos, 2020, s. 77).

Çakın ve Akyavuz (2020) tarafından 20 öğretmenle yapılan araştırmada uzaktan eğitimde sınıf öğretmenleri ve bazı branşlarda öğretmenleri zorlayan durumlar değerlendirilmiş bunları iletişim sorunları, velilerle sorunlar ve öğrencilerin öğrenmesi ile ilgili olanlar olarak tespit ve kategorize etmiştir (Çakın ve Akyavuz, 2020, s. 180-181).

Fidan (2020, s.29), tarafından uzaktan eğitimin olumsuz yönleri ile ilgili olarak 23 katılımcı sınıf öğretmeninin görüşlerine başvurarak yaptığg araştırmada veliler, rahatlık, sınıf yönetimi vb. 74 adet olumsuz durum tespitinde bulunulmuştur (Fidan, 2020, s. 32).

$\mathrm{Bu}$ çalışmanın covid-19 salgın hastalık sürecinde yapılan uzaktan eğitim ile ilgili sınıf öğretmenlerinin $\quad$ yaşadıkları sorunları irdeleyen çalışmalara katıkı sunacağı 
değerlendirilmektedir. Çalışma covid-19 pandemi sürecinde görev yapan sınıf öğretmenlerinin yaşadığı sorunları tespit etmek ve bu sorunlara çözüm önerileri sunmak üzere yapılmıştır. Özellikle tüm dünyanın çaresiz kaldığı salgın hastalık süreci içerisinde eğitim öğretim faaliyetlerinin sekteye uğratacak sorunların tespiti ve çözüm önerileri sunma isteği çalışmanın çıkış noktası olmuştur. Araştırmanın problem cümlesi 'Covid-19 Pandemi Sürecinde Sınıf Öğretmenlerinin Karşılaştığı Sorunların Belirlenmesi” şeklinde belirlenmiştir. $\mathrm{Bu}$ çalışma ile salgın hastalık nedeniyle yaşanan zorunlu uzaktan eğitim faaliyetlerinde Karatay ilçesi özelindeki ilkokullarda görev yapan sınıf öğretmenlerinin karşılaştıkları güçlükleri tespit ederek; eğitim öğretimin kesintisiz devam etmesi için bu sorunlara çözüm önerileri sunmak hedeflenmiştir.

\section{Araştırmanın Amacı}

$\mathrm{Bu}$ araştırmada covid-19 pandemi sürecinde sınıf öğretmenlerinin uzaktan eğitim alanında karşılaştığı sorunların tespit edilmesi ve bu sorunlara çözümler önerilmesi amaçlanmaktadır.

\section{Araştırmanın Önemi}

Araştırmadan elde edilen sonuçlar çerçevesinde temel eğitimin mihenk taşı konumunda bulunan ilkokullarda eğitim öğretim hizmetlerini veren sınıf öğretmenlerinin covid-19 pandemi nedeniyle yapılan uzaktan eğitim faaliyetlerindeki karşılaştığı sorunlarının giderilmesi öngörülmektedir.

Temel eğitim okullarında eğitim ve öğretim faaliyetlerinin verimli ve işlevsel olarak kesintisiz olarak sürdürülebilirliği konusunda araştırma sonuçları önem arzetmektedir.

\section{Yöntem}

\section{Araştırma Modeli}

Karatay ilçesinde covid-19 pandemi uzaktan eğitim sürecinde sınıf öğretmenlerinin karşılaştığı sorunların belirlenmesi amacıyla yapılan bu araştırmada nicel bir araştırma yolu izlenmiştir. Nicel araştırma yöntemlerinden Tarama modeli kullanılmıştır. Tarama modelinde veriler evrenin kesitsel bir grubundan toplanır, veriler grup üyelerinin verdikleri cevaplardan oluşur (Atalay ve Mazlum, 2017, s. 5-6). Araştırmada katılımcıların bilgisine doğal ortamlarında başvurulmuş, mevcut durumları da dikkate alınarak sorunlar ortaya çıkarılmaya çalışılmıştır. Nicel araştırma yöntemlerinden anket tekniği ile veriler toplanarak analiz edilmiştir. 


\section{Araştırma Alanı ve Katılımcılar}

Araştırmanın evreni Karatay ilçesinde görev yapan sınıf öğretmenleridir. Örneklem ise, Karatay ilçesinde görev yapan sınıf öğretmenlerinden random usulü ile belirlenen ve gönüllü katılım gösteren kırk öğretmenden oluşmaktadır. Araştırmaya katılan sınıf öğretmenlerinin demografik özellikleri Tablo 1 'de gösterilmektedir.

\begin{tabular}{|c|c|c|}
\hline Demografik Özellik & Sayı $(f)$ & Yüzde (\%) \\
\hline \multicolumn{3}{|l|}{ Cinsiyet } \\
\hline Kadın & 17 & 42,5 \\
\hline Erkek & 23 & 57,5 \\
\hline \multicolumn{3}{|l|}{ Mesleki Kıdem } \\
\hline $1-5 y l l$ & 2 & 5 \\
\hline 6-10yll & 2 & 5 \\
\hline $11-15 y l l$ & 12 & 30 \\
\hline $16-20 y z l$ & 10 & 25 \\
\hline $21+y l l$ & 14 & 35 \\
\hline \multicolumn{3}{|l|}{ Sinıf Mevcudu } \\
\hline 0-21 öğrenci & 11 & 27,5 \\
\hline 21-40 öğrenci & 28 & 70 \\
\hline 41-60 ögrenci & 1 & 2,5 \\
\hline \multicolumn{3}{|c|}{ Teknolojik İmkan (Kişisel Bilgisayar) } \\
\hline Var & 35 & 87,5 \\
\hline Yok & 5 & 12,5 \\
\hline \multicolumn{3}{|l|}{ Okutulan Sinıf } \\
\hline 1.Sinif & 8 & 20 \\
\hline 2.Sinif & 14 & 35 \\
\hline 3.Sinif & 7 & 17,5 \\
\hline 4.Sinif & 11 & 27,5 \\
\hline \multicolumn{3}{|l|}{ Aylık Gelir } \\
\hline $0-3000 T L$ & 1 & 2,5 \\
\hline $3001-6000 T L$ & 33 & 82,5 \\
\hline $6001-9000 T L$ & 4 & 10 \\
\hline $9001+T L$ & 2 & 5 \\
\hline \multicolumn{3}{|l|}{ Mezuniyet Durumu } \\
\hline Lisans & 39 & 97,5 \\
\hline Yüksek Lisans & 1 & 2,5 \\
\hline
\end{tabular}


Tablo 1'de ankete katılan sınıf öğretmeni sayısı kırktır. Katılımcıların beş tanesinin evinde kendisine ait bilgisayarının olmadığı görülmektedir. Ankete cevap veren sınıf öğretmenlerinin tamamının yüksek öğretim mezunu olduğu anlaşılmaktadır. Ankete cevap veren sınıf öğretmenlerinden bir tanesi aylık 3000 TL altında gelir beyan ettiğinden ücret karşılığ görev yapan bir öğretmen olduğu değerlendirmektedir. Sınıf mevcutlarının sadece bir tanesinin kırk öğrencinin üzerinde olduğu anlaşılmakta ve katılımcıların \% 97,5' inin sınıf mevcutlarının kırk öğrenciden az olduğu görülmektedir. Sınıf öğretmenlerinin tamamının müstakil sınıf okuttuğu, mesleki kıdem olarak 16 yıl ve daha fazla olan öğretmen yüzdesinin 60 olduğu anlaşılmaktadır. Ankete katılan erkek sınıf öğretmeni sayısı kadınlardan fazladır.

\section{Veri Toplama Araçları}

Araştırma kapsamında verilerin toplanması oluşturulan anket formu kapsamında anket tekniği ile yapılmıştır. Anket tekniği önceden belirlenen sorular çerçevesinde disiplinli bir veri toplama tekniği olarak bilinmektedir (Yılmaz vd., 2020, s. 16). Anketin planlanması iki bölüm olarak gerçekleştirilmiştir. Birinci bölümde katılımcı sınıf öğretmenlerinin demografik yapılarını belirlemek amacı ile toplam sekiz soru yöneltilerek durumlarını belirtmeleri istenmiştir. İkinci bölümde katılımcı sınıf öğretmenlerinin covid-19 pandemi sürecinde yapılan uzaktan eğitim öğretim faaliyetlerinde karşılaşmaları muhtemel sorunlar derlenerek kendilerine yöneltilmiş ve kendilerine uygun olan seçeneği EVET, KISMEN, HAYIR şeklinde belirtmeleri istenmiştir. Salgın sebebiyle anket formu yüz yüze katılımcıların doldurması istenmemiş, google formlar aracılığı ile katılımcılara ulaştırılmıştır.

\section{Veri Toplama Süreci}

Katılımcılara ölçme aracı olarak oluşturulan anket formu ulaştırılarak cevaplamaları istenmiştir. Çalışma için oluşturulan anket formu cevaplaması kolay, yönergeleri anlaşılır olarak iki bölümden meydana gelmektedir. Birinci bölümde katılımcıların demografik özelliklerini belirleyen sekiz adet soru, ikinci bölümde sınıf öğretmenlerinin uzaktan eğitim sürecinde karşılaşabilecekleri muhtemel sorunları tespit edebilecek yirmi yedi adet soru bulunmaktadır. Korona virüs salgın hastalığg sebebiyle veriler 2020 Kasım ayında yüz yüze toplanamamış, google formlar aracılı̆̆ı ile okul yöneticilerin katkısı ile Karatay ilçesinde görev yapan random usul ile belirlenen gönüllü sınıf öğretmenlerine elektronik ortamda bire bir ulaştırılmış ve anket formunu cevaplamaları sağlanmıştır. 


\section{Veri Analizi}

Ankete katılan sınıf öğretmenlerinin cevapları birlikte değerlendirilerek analiz edilmiştir. Elde edilen bulgular literatüre dayalı olarak çıkarımlarda bulunulmuştur. Verilerin çözümlenmesinde betimsel analiz yöntemi kullanılarak bütünsel bir bakış açısı kullanılmıştır. Verilerin çözümlenmesi neticesinde elde edilen sonuçlara bulgular bölümünde yer verilmiştir.

\section{Bulgular ve Yorumlar}

Korona virüs salgın hastalık sürecinde ölçme aracına katılan sınıf öğretmenlerinin durumlarına ilişkin bulgular Tablo 2'deki gibidir.

\begin{tabular}{|c|c|c|c|c|c|c|}
\hline \multirow[t]{2}{*}{ Soru } & \multirow{2}{*}{$\frac{\text { Evet }}{f}$} & \multicolumn{3}{|c|}{ Kismen } & \multicolumn{2}{|c|}{ Hayır } \\
\hline & & $\%$ & $f$ & $\%$ & $f$ & $\%$ \\
\hline S1 İkametgahım öğrencilerimin ikametgahlarına yakındır. & 8 & 20 & 17 & 42,5 & 15 & 37,5 \\
\hline $\begin{array}{l}\text { S2 Görev yaptı̆̆ım okulun teknolojik alt yapısı ve internet } \\
\text { alt yapısl yeterlidir. }\end{array}$ & 9 & 22,5 & 19 & 47,5 & 12 & 30 \\
\hline $\begin{array}{l}\text { S3 Öğrencilerin uzaktan eğitime katılma ve devam durumu } \\
\text { yeterlidir. }\end{array}$ & 3 & 7,5 & 25 & 62,5 & 12 & 30 \\
\hline $\begin{array}{l}\text { S4 Uzaktan eğitim sürecinde diğer meslektaşlarımla olan } \\
\text { iletişimim yeterlidir. }\end{array}$ & 26 & 65 & 12 & 30 & 2 & 5 \\
\hline $\begin{array}{l}\text { S5 Uzaktan ĕ̈itim sürecinde sinıf öğretmeni olarak öğrenci } \\
\text { başarısı ölçülüp değerlendirilmektedir. }\end{array}$ & 10 & 25 & 27 & 67,5 & 3 & 7,5 \\
\hline $\begin{array}{l}\text { S6 Uzaktan eğitim sürecinde sinlf öğretmeni olarak } \\
\text { günlük-haftallk-aylık çalışmalar planlanmaktadır }\end{array}$ & 21 & 52,5 & 19 & 47,5 & 0 & 0 \\
\hline $\begin{array}{l}\text { S7 Uzaktan eğitim sürecinde sinıf öğretmeni olarak } \\
\text { hazırladlğım günlük-haftallk-aylık plan uygulanmaktadır. }\end{array}$ & 17 & 42,5 & 20 & 50 & 3 & 7,5 \\
\hline $\begin{array}{l}\text { S8 Uzaktan eğitim sürecinde öğrencilere bireysel çalışma } \\
\text { alışkanlı̆̆l verilmektedir. }\end{array}$ & 17 & 42,5 & 21 & 52,5 & 2 & 5 \\
\hline $\begin{array}{l}\text { S9 Ölçme ve değerlendirme yapıldıktan sonra eksik olan } \\
\text { kazanımlar ögrencilere verilmektedir. }\end{array}$ & 13 & 32,5 & 26 & 65 & 1 & 2,5 \\
\hline $\begin{array}{l}\text { S10 Uzaktan eğitim sürecinde EBA alt yapısın } \\
\text { kullanmaktayım }\end{array}$ & 32 & 80 & 6 & 15 & 2 & 5 \\
\hline $\begin{array}{l}\text { S11 Uzaktan eğitim sürecinde öğrencilerim derslere } \\
\text { katılmaktadır. }\end{array}$ & 9 & 22,5 & 28 & 70 & 3 & 7,5 \\
\hline $\begin{array}{l}\text { S12 İlköğretim programinda belirtilen ilköğretim amaçları } \\
\text { uzaktan eğitim sürecinde gerçekleştirilmektedir. }\end{array}$ & 9 & 22,5 & 29 & 72,5 & 2 & 5 \\
\hline $\begin{array}{l}\text { S13 İlköğretim programinda belirtilen metot ve teknikler } \\
\text { uzaktan eğitim sürecinde uygulanabilmektedir. }\end{array}$ & 6 & 15 & 28 & 70 & 6 & 15 \\
\hline $\begin{array}{l}\text { S14 Uzaktan eğitim sürecinde dersleri işlerken yeterli } \\
\text { materyaller kullanılmaktadır. }\end{array}$ & 12 & 30 & 19 & 47,5 & 9 & 22,5 \\
\hline $\begin{array}{l}\text { S15 Uzaktan ĕgitim sürecinde sinıf öğretmeni olarak eğitim } \\
\text { teknolojilerini kullanıyorum. }\end{array}$ & 26 & 65 & 13 & 32,5 & 1 & 2,5 \\
\hline $\begin{array}{l}\text { S16 Görev yaptı̆̆ım okul çevresinin hitap ettiği öğrenciler } \\
\text { teknolojik donanım (internet, tablet, bilgisayar vb.) } \\
\text { yönünden yeterlidir. }\end{array}$ & 5 & 12,5 & 19 & 47,5 & 16 & 40 \\
\hline
\end{tabular}




\begin{tabular}{|c|c|c|c|c|c|c|}
\hline S17 Uzaktan eğitim ile verimli ders işlenmektedir. & 9 & 22,5 & 27 & 67,5 & 4 & 10 \\
\hline $\begin{array}{l}\text { S18 Sinıf ögretmeni olarak yapılacak çalışmalar } \\
\text { ögrencilerle birlikte planlayıp değerlendirilmektedir. }\end{array}$ & 5 & 12,5 & 18 & 45 & 17 & 42,5 \\
\hline $\begin{array}{l}\text { S19 EBA (Ĕ̆itim Bilişim Ă̆ı) alt yapısı uzaktan eğitim } \\
\text { ihtiyaçlarını karşılamaktadır. }\end{array}$ & 15 & 38,5 & 22 & 55 & 3 & 7,5 \\
\hline $\begin{array}{l}\text { S20 Uzaktan eğitim uygulamalarında beceri dersleri } \\
\text { (resim, müzik, beden eğitimi ve oyun) için ögrencilere } \\
\text { müfredat programı kapsamında sahip olması gereken } \\
\text { kazanımlar verilmektedir. }\end{array}$ & 7 & 17,5 & 23 & 57,5 & 10 & 25 \\
\hline $\begin{array}{l}\text { S21 EBA 'dan farklı uzaktan eğitim araçlarını } \\
\text { kullanmaktayım. }\end{array}$ & 17 & 42,5 & 17 & 42,5 & 6 & 12,5 \\
\hline $\begin{array}{l}\text { S22 Mezun olduğum öğretim kurumunda, uzaktan eğitim } \\
\text { ögretim çalışmalart ile ilgili yeterli bilgi ve beceriyi } \\
\text { kazandım. }\end{array}$ & 8 & 20 & 14 & 35 & 18 & 45 \\
\hline $\begin{array}{l}\text { S23 Uzaktan ĕgitimin zorlukları (alt yapı eksikliği, iletişim } \\
\text { sorunu, ögrencilerin yaş grubu, dezavantajlı gruplar) } \\
\text { denetlemelerde dikkate alınmaktadır. }\end{array}$ & 17 & 42,5 & 16 & 40 & 7 & 17,5 \\
\hline $\begin{array}{l}\text { S24 Uzaktan eğitim sürecinde ögrenci velilerimiz destek } \\
\text { vermektedir. }\end{array}$ & 15 & 37,5 & 25 & 62,5 & 0 & 0 \\
\hline $\begin{array}{l}\text { S25 Uzaktan eğitimde dersler için ayrllan süre konuları } \\
\text { işleyebilecek yeterliliktedir. }\end{array}$ & 14 & 35 & 15 & 37,5 & 11 & 27,5 \\
\hline $\begin{array}{l}\text { S26 Uzaktan eğitim sürecinde rehberlik ihtiyaçlarımız } \\
\text { karşılanmaktadır. }\end{array}$ & 16 & 40 & 17 & 42,5 & 7 & 17,5 \\
\hline $\begin{array}{l}\text { S27 Uzaktan ĕgitim sürecinde eğitim ögretim faaliyetleri } \\
\text { için alınan kararları zamanında takip ediyorum. }\end{array}$ & 31 & 77,5 & 8 & 20 & 1 & 2,5 \\
\hline
\end{tabular}

Sınıf öğretmenlerinin kısmen ikametlerinin öğrencilerin ikametine yakın olduğu değerlendirilmektedir. Sınıf öğretmenlerinin görev yaptığı okulun teknolojik alt yapılarının uzaktan eğitim için yeterli olduğunu ifade edenler \%9 da kalmaktadır. Öğrencilerin uzaktan eğitime katılma devam durumlarının yeterli olduğunu ifade eden sınıf öğretmeni sayısı 3/40 olarak gerçekleşmektedir. Sınıf öğretmenlerinin salgın sürecinde meslektaşları ile iletişimlerinin sağlıklı bir şekilde gerçekleştirdikleri anlaşılmaktadır. Pandemi sürecinde öğrenci başarısını ölçüp değerlendirebilen sınıf öğretmeni yüzdesi \%25 olarak kalmıştır. Kısmen ölçme değerlendirme yapabilen sınıf öğretmeni oranı \% 67,5 olarak gerçekleşmiştir. Sınıf öğretmenlerinin günlük, haftalık ve aylık planları yaptıkları bulgusuna ulaşılmaktadır. Hazırlanan bu günlük, haftalık ve aylık planları uygulama oranı \%50 ya yakındır. Kısmen uygulayabiliyorum şeklinde cevap veren öğretmen sayısı 20 kişidir. Ankete katılan sınıf öğretmenlerinin yarısından fazlası öğrencilere bireysel çalışma alışkanlığı kazandırabildikleri ve eksik kazanımları kısmen de olsa ölçme değerlendirme işleminden sora verebildiklerini ifade etmektedir. Katılımcıların \%80’i EBA alt yapısını kullandığını belirtmiştir. Uzaktan eğitim canlı derslerine bilgisine başvurulan sınıf öğretmenlerinin \%70’i öğrencilerin kısmen katılabildiklerini belirtmişlerdir. 
Sınıf öğretmenlerinin \% 72,5'lik bir kısmı ilköğretimin amaçlarının kısmen gerçekleştirilebildiği görüşünü ifade etmiştir. Derslerin uzaktan eğitim yöntemiyle işlenişinde amaçlar doğrultusunda yöntem ve tekniklerin $\% 70$ ve üstü oranında kısmen kullanılabildiği belirtilmiştir. Görev yapılan çevrenin öğrencilerinin teknolojik alt yapı durumları konusunda belirgin bir şekilde ayrıştığı görülmektedir. Uzaktan eğitime rağmen verimli bir ders işleyebildiğini kısmen veya tamamen düşünen sınıf öğretmeni oranı yüzde 80 civarındadır. EBA alt yapısının uzaktan eğitim ihtiyacını kısmen karşılandığı belirtilmektedir. Görsel sanatlar, müzik, beden eğitimi ve oyun gibi beceri gerektiren derslerde kazanımları kısmen verebildikleri değerlendirilmektedir. EBA' nın yanında başka uzaktan eğitim araçlarını da kullana sınıf öğretmeni oranının yüzde 40 ve üzeri olduğu anlaşılmaktadır. Sınıf öğretmenlerinin büyük çoğunluğu mezun olduğu yüksek öğretim programında uzaktan eğitim ile ilgili bilgi ve beceriyi edinmediklerini ifade etmiştir. Sınıf öğretmenleri uzaktan eğitim sürecinde rehberlik ihtiyaçlarının kısmen veya tamamen karşılandığını, uzaktan eğitim ile ilgili gelişmeleri zamanında öğrenebildiklerini belirtmektedirler. Karatay ilçesi özelinde ankete katılan sınıf öğretmenlerinin yarısından fazlasının erkek olduğu belirlenmiştir. Mesleki kıdem olarak değerlendirildiğinde kıdemli sınıf öğretmenlerinin çoğunluğu oluşturduğu anlaşılmaktadır. Sınıf öğretmenlerinin yüzde yetmişlik bir kısmının sınıf mevcudunun 21 ile 40 arasında olduğu görülmektedir. Sınıf öğretmenlerinin büyük çoğunluğun 3.000- 6.000 Türk lirası aylık gelire sahip olduğu görülmektedir. Ankete katılan sınıf öğretmenlerinden beş tanesinin kendi kişisel bilgisayarının olmadığı tespit edilmiştir. Ankete katılan sınıf öğretmenlerinden öğrencilerin ikametlerine yakın yerlerde ikamet etmedikleri değerlendirilmektedir. Uzaktan eğitim faaliyetlerine katılan ve ölçme aracına fikir beyan eden sınıf öğretmenlerinin tamamının yüksek öğretim mezunu olduğu görülmektedir.

Görev yaptığı okulların teknolojik alt yapılarının yetersiz olduğu saptanmaktadır. Bilindiği üzere 2011-2012 eğitim öğretim yılından itibaren uygulanmaya konulan FATİH Projesi Faz I ve Faz II kapsamında ortaokul ve liseler teknolojik açıdan desteklenmiş ancak ilkokullara bu konuda akıllı tahta kurulumları yapılmamıştır. Bu durum görev yapılan eğitim kurumundaki teknolojik alt yapı yetersizliğini desteklemektedir.

Öğrencilerin uzaktan eğitimde devam durumlarının yeterli olmadıkları değerlendirilmektedir. $\mathrm{Bu}$ durum teknolojik yetersizlik veya uzaktan eğitimin; devam zorunluluğu olmadığından öğrenciler tarafından ciddiye alınmadığını gösterebilir.

Uzaktan eğitim sürecinde sınıf öğretmenlerinin meslektaşlarıyla karşılıklı iletişim halinde oldukları değerlendirilmektedir. 
Gerçek manada ölçme-değerlendirme yapabilen sınıf öğretmeni yüzdesi 25 olarak belirlenmektedir. Pandemi döneminde uzaktan eğitimde sınıf öğretmenlerinin öğrencilerine bireysel çalışma alışkanlığı kazandırabildikleri anlaşılmaktadır. Ölçme ve değerlendirme işleminden sonra eksik kazanımları verebildikleri ancak ölçme ve değerlendirmenin tam anlamıyla yapılamadığı saptanmaktadır.

Uzaktan eğitim canlı derslerine öğrencilerin kısmen katıldığını beyan eden sınıf öğretmeni oranı yüzde yetmiştir. İlköğretim programları kapsamında ulaşılması gereken amaçlara kısmen ulaşıldığını düşünen sınıf öğretmeni oranı \%72,5 olarak gerçekleşmiştir. Derslerin canlı dersle olarak işlenişinde uygulanacak yöntem ve teknikerin \%70 oranında kullanılabildiği saptanmıştır. Sınıf öğretmenlerinin görev yaptığı çevreden gelen öğrencilerin teknolojik donanımlarının yetersiz olduğu değerlendirilmektedir. Sınıf öğretmenleri MEB tarafından uzaktan eğitim tedbirleri kapsamında alınan kararları ve gelişmeleri zamanında haberdar olduklarını, uzaktan eğitim ile ilgili kendilerine yapılan rehberliğin yeterli olduğunu düşünmektedirler.

\section{Tartışma ve Sonuç}

Sınıf öğretmenlerinin değerlendirmelerinde EBA' nın içerik ve alt yapı olarak yeterli olduğu değerlendirilmesinin yanında çeşitli uzaktan eğitim uygulamalarını kullanıldığı saptanmıştır. Özer'in araştırmasına göre Milli Eğitim Bakanlığı, TRT ile işbirliğine gitmiş ve EBA altyapısını güçlendirmeye çalıştığı belirlenmiştir (Özer, 2020, s. 1126). Görev yapılan çevrenin sosyoekonomik durumuna bağlı olarak öğrencilerin teknolojik olarak donanım eksikliklerinin bulunduğu sonucuna ulaşıldığından bu çevreden gelen öğrencilerin uzaktan eğitime eksiksiz katılabilmeleri için desteklenmeleri gerekmektedir. Yılmaz ve arkadaşlarının araştırmasına göre pek çok ülke internet altyapısını kullanmış, kimisi de televizyon programları aracılığıyla uzaktan eğitime devam etmiştir (Yılmaz vd., 2020, s. 7-8). Ayrıca uzaktan eğitim canlı derslerine katılım oranın yetersiz olduğu sonucuna ulaşılmaktadır. Fidan (2020, s. 34) da uzaktan eğitim sürecinde öğrencilerin rahat davranmalarından bahsetmektedir. Uzaktan eğitim sürecinde sınıf öğretmenlerince ölçme değerlendirme çalışmalarının tam anlamıyla yapılamadığı sonucuna ulaşılmaktadır. Bu duruma Çakın ve Akyavuz (2020, s.181) öğrencilerin öğrenmeleri ile ilgili olan sorunlar da yer vermektedir Sınıf öğretmenlerinin görev yaptıkları ilkokulların teknolojik alt yapısının yetersiz olduğu değerlendirilmektedir. Az da olsa sınıf öğretmenleri arasında kişisel bilgisayarı olmayanlar bulunmaktadır. Teknolojik alt yapısı eksik olan öğrencilerle Kantos iletişim sorunları yaşandığını ifade etmektedir (Kantos, 2020, s. 77). Sınıf öğretmenlerinin mezun oldukları yüksek öğretim kurumunda uzaktan eğitimin sevk ve idaresi ile ilgili bilgi ve beceri 
kazanmadıkları sonucuna varılmaktadır. Bu durum Fidan'ın (2020, s. 34) uzaktan eğitimin olumsuz yönleri ile ilgili yaptığı araştırmasında ele aldığı sınıf yönetimi sorunu ile ilişkilendirilebilir.

\section{Öneriler}

Araştırma katılımcılar olan Konya ili Karatay ilçesi ilkokullarında görev yapan sınıf öğretmenleri ile sınırlıdır. Elde edilen bilgi ve bulgular araştırmacı tarafından katılımcı sınıf öğretmenlerine yöneltilen ölçme aracındaki sorular ve sınıf öğretmenlerinden alınan cevaplar ve 2020 y1lı ile sinırlıdır.

Milli Eğitim Bakanlığı tarafından aynı anda çok daha fazla kullanıcıya hitap edecek şekilde EBA bağlantı kapasitesinin arttırılması önerilebilir. Ekonomik durumu kötü olan öğrenciler teknolojik imkanlarla desteklenmelidir. Teknolojik alt yapı olarak desteklenen tüm öğrencilere canlı derslerde yoklama zorunluluğu getirilmelidir. Sınıf öğretmenlerinin öğrencilerin edinmesi gereken eksik kazanımları, ölçme ve değerlendirmeden sonra öğrencilere kazandırdıkları düşünüldüğünde uzaktan eğitimde öğrencilerin sahip olması gereken kazanımları ölçebilecek güvenilir ölçme araçlarının uzaktan eğitim sürecinde oluşturulması ve kullanılması gerekmektedir. Bu sorununun çözümü için EBA alt yapısı daha da geliştirilmelidir.

Teknolojik alt yapı eksikliğinin giderilebilmesi için; Fatih Projesinin devamı olan Faz III çalışmalarının hızlandırılarak ilkokulların da internet alt yapısının iyileştirilerek ve akıllı tahta uygulamalarının kazandırılması önerilmektedir.

Sınıf öğretmenlerinin uzaktan eğitimi sorunsuz bir şekilde gerçekleştirebilmeleri ve eğitim öğretimin kesintiye uğramaması adına teknolojik araçlarla sınıf öğretmenleri desteklenmelidir. Böylece iletişim sorunları ortadan kaldırılabilecektir.

Uzaktan eğitim sürecinde sınıf yönetimi konusunda karşılaşılan sorunların çözümü için eğitim fakültelerinde uzaktan eğitim ile ilgili derslerin verilebileceği düşünülmektedir. Halen görevde olan sınıf öğretmenleri için ise Milli Eğitim Bakanlığı tarafından hizmet içi eğitim faaliyetleri gerçekleştirilebilir. 


\section{Kaynakça}

Ağır, F., (2007), Özel Okullarda ve Devlet Okullarında Çalışan İlköğretim Öğretmenlerinin Uzaktan Eğitime Karşı Tutumlarının Belirlenmesi, Yayınlanmamış Yüksek Lisans Tezi, Balıkesir

Akyürek, M., İ., (2020), Uzaktan eğitim: Bir alanyazın taraması, Medeniyet Ĕ̈itim Araştırmaları Dergisi, cilt: 4, sayı:1, 1-9

Balaban, M., E., (2012), Dünyada ve Türkiye'de Uzaktan Eğitim ve Bir Proje Önerisi.

Başaran, M., Doğan, E., Karaoğlu, E., Şahin, E., (2020), Koronavirüs (Covıd-19) Pandemi sürecinin getirisi olan uzaktan eğitimin etkililiği üzerine bir çalışma, Academia Ĕ̆itim Araştırmaları Dergisi, 5(2), 368-397

Bozkurt, A., (2017), Türkiye'de uzaktan eğitimin dünü, bugünü ve yarını, Açıköğretim Uygulamaları ve Araştırmaları Dergisi, cilt: 3, sayl: 2, ss: 85- 124

Bozkurt, A., (2020), Koronavirüs (Covid-19) pandemi süreci ve pandemi sonrası dünyada eğitime yönelik değerlendirmeler: yeni normal ve yeni eğitim paradigması, Açıköğretim Uygulamaları ve Araştırmaları Dergisi, 112-142

Can,. E., (2020), Coronavirüs (Covid19) pandemisi ve pedagojik yansımaları: türkiye'de açık ve uzaktan eğitim uygulamaları, Açıköğretim Uygulamaları ve Araştırmaları Dergisi, $11-53$

Çakın, M., Akyavuz, E.; K., (2020), Covid-19 süreci ve eğitime yansıması: öğretmen görüşlerinin incelenmesi, International Journal of Social Sciences and Education Research, 6(2)

Dikmen, A., U., Kına, H., M., Özkan, S., İlhan, M.,N., (2020), Covid-19 epidemiyolojisi: pandemiden ne öğrendik? , Journal of Biotechnology and Strategic Health Research, 29- 36

Erdinç Koçer, H., (2001), Web Tabanlı Uzaktan Eğitim, Yayınlanmış Yüksek Lisans Tezi, Konya.

Fidan, M., (2020) , Covid-19 belirsizliğinde eğitim: ilkokulda zorunlu uzaktan eğitime ilişkin öğretmen görüşleri, Uşak Üniversitesi Eğitim Araştırmaları Dergisi, 24-43

Gökçe, A., T. (2008), Küreselleşme sürecinde uzaktan eğitim, D. Ü. Ziya Gökalp Ĕgitim Fakültesi Dergisi, 11, 1-2

Göksel Canbek, N., (2015). Uzaktan öğretme ve öğrenme: uzaktan eğitimin temelleri, Açık Öğretim Uygulamaları ve Araştırmaları Dergisi, cilt: 1 , sayı: 2, ss 102-111

Hatipoğlu, Z., Herand, D. (2014), Uzaktan eğitim ve uzaktan eğitim platformlarının karşılaştırılmas1, Çukurova Üniversitesi İ̈BF Dergisi, cilt: 18, sayı:1 , ss 65-75 
Karatepe, F., Küçükgencay, N., Peker, B., (2020), Öğretmen adayları senkron uzaktan eğitime nasıl bakıyor? bir anket çalışması, Uluslararası Sosyal ve Beşeri Bilimler Araştırması Dergisi, 7(53), 1262-1274

Kantos, Z., E. (2020), Sınıf Öğretmenlerinin Uzaktan Eğitim İle İlgili Düşünceleri, Uluslararası Bilimsel Araştırmalar Kongresi - Sosyal ve Ĕ̆itim Bilimleri- Asos Yayınları, Hattuşa, Çorum.

Kaya, Z., (2002), Uzaktan Eğitim, Pegem A Yayınları, Ankara.

Keskin, M., Özer Kaya, D., (2020), Covid19 sürecinde öğrencilerin web tabanlı uzaktan eğitime yönelik geri bildirimlerinin değerlendirilmesi, İzmir Katip Çelebi Üniversitesi Să̆lık Bilimleri Fakültesi Dergisi, 5(2), 59-67

Kilıç, S., (2013), Örnekleme yöntemleri, Journal of Mood Disorders, 3-1, $44-46$

Kırık, A.,M., (2014), Uzaktan eğitimin tarihsel gelişimi ve türkiye'deki durumu, Marmara İletişim Dergisi, sayı: 21, ss: 73- 94.

Mazlum, M., M., Atalay, A., (2017), Sosyal bilimlerde araştırma yönteminin belirlenmesi, Route Educational and Social Science Journal, 1-21

Özbay, Ö., (2015), Dünyada ve türkiye'de uzaktan eğitimin güncel durumu, Uluslararası Eğitim Bilimleri Dergisi, Yll: 2, Sayl: 5, s.376- 394.

Özer, M., (2020), Türkiye'de covid19 salgını sürecinde milli eğitim bakanlığı tarafından atılan politika adımları, Kastamonu Education Journal, 2883), 1124-1129

Sarı, H., İ., (2020), Evde kal döneminde uzaktan eğitim: ölçme ve değerlendirmeyi neden karantinaya almamalıyız?, Uluslararası Eğitim Araştırmacıları Dergisi, 3(1), 121-128

Telli Yamamato, G., Altun, D., (2020), Coronavirüs ve çevrimiçi (online) eğitimin önlemeyene yükselişi, Üniversite Araştırmaları Dergisi, cilt: 3, sayı: 1, ss: 25-34

Toker Gökçe, A., (2008), Küreselleşme sürecinde uzaktan eğitim, D. Ü. Üniversitesi Ziya Gökalp Ĕ̆itim Fakültesi Dergisi 11, 1-12.

Uşun, S., (2006), Uzaktan Eğitim, Nobel Yayınları, Ankara

Yıldırım, K., (2020), İstisnai bir uzaktan eğitim-öğretim deneyiminin öğrettikleri, Alanyazın Ĕ̈itim Bilimleri Eleştirel Ínceleme Dergisi, cilt: 1, sayl:1

Yılmaz, E., Mutlu, H., Güner, B., Doğanay, G., Yılmaz, D., (2020), Veli Algısına Göre Pandemi Dönemi Uzaktan Eğitimin Niteliği, Palet Yayınları, Konya.

(WHO), https://www.who.int/emergencies/diseases/novel-coronavirus-2019

MEB, http://www.meb.gov.tr/ebada-canli-sinifla-egitimbasliyor/haber/20602/tr?fbclid=IwAR2xOWtortAlufruf24E9cjTeEQmomDEl92WODZ3 2RD78UJkFqIIFnZSiVI, 29 Mart 2020 
AA., (3 Mart 2020), https://www.aa.com.tr/tr/koronavirus/saglik-bakani-koca-turkiyede-ilkkoronavirus-vakasinin-goruldugunu-acikladi/1761466

https://tr.wikipedia.org/wiki/EBA\#: : text $=2011 \% 2 D 2012 \% 20 e \% C 4 \% 9 F i t i m \% 20 \%$ C3\%B6\% C4\%9Fretim\%20y\%C4\%B11\%C4\%B1nda,Bili\%C5\%9Fim\%20A\%C4\%9F\%C4\%B1\% 20(EBA)\%20kurulmu\%C5\%9Ftur.

https://tr.wikipedia.org/wiki/Zat\%C3\%BCrre\#Belirtiler_ve_semptomlar

WHO, https://www.who.int/health-topics/coronavirus\#tab=tab_3

MEB, http://www.meb.gov.tr/meb_duyuruindex.php?KATEGORI=2978

CNNTÜRK, https://www.cnnturk.com/turkiye/egitim-ogretim-yili-sona-erdi

MEB, https://merkezisgb.meb.gov.tr/www/egitim-kurumlarinda-hijyen-sartlariningelistirilmesi-ve-enfeksiyon-onleme-kontrol-kilavuzu/icerik/244

MEB, http://www.meb.gov.tr/okul-oncesi-egitim-ve-1-siniflar-yuz-yuze-egitimebasliyor/haber/21614/tr

MEB, http://www.meb.gov.tr/okullarda-yuz-yuze-egitimde-ikinci-asama-12-ekim-pazartesigunu-basliyor/haber/21776/tr

MEB, http://www.meb.gov.tr/egitim-ogretim-31-aralik-2020ye-kadar-online-olaraksurdurulecek/haber/21983/tr https://www.resmigazete.gov.tr/eskiler/2020/05/20200508-2.htm TEGM, http://tegm.meb.gov.tr/www/12-ekim-2020-tarihinden-itibaren-ilkokul-1-2-3-4siniflar-ile-ortaokul-8-sinifta-yuz-yuze-egitimlerde-uygulanacak-haftalik-derscizelgeleri/icerik/689

MEB, https://www.meb.gov.tr/trt-eba-tv-21-25-eylul-ders-programi/haber/21665/tr 


\section{Yazarlar Hakkında}

\section{Halil SAYGI}

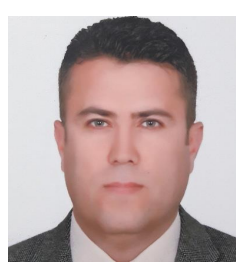

Selçuk Üniversitesi Ahmet Keleşoğlu Eğitim Fakültesi Sınıf Öğretmenliği Ana Bilim Dalı mezunudur. 2005 yılında Milli Eğitim Bakanlığı'nda Müdür Yetkili Sınıf Öğretmeni olarak başladığı mesleğine ülkemizin çeşitli yerlerinde sınıf öğretmenliği, müdür yardımcılığı ve okul müdürlüğü görevlerinde bulunmuştur. Halen Konya ili Karatay ilçesi Çatalhüyük Munise Lütfi Onat İlkokulu'nda okul müdürü olarak görev yapmaktadır. Yüksek lisansını Necmettin Erbakan

Üniversitesi Eğitim Bilimleri Enstitüsü’nde Eğitim Yönetimi alanında yapmıştır. Devlet memurluğunun yanında eğitim bilimleri alanında bilimsel araştırmalar yaparak hakemli dergilere makaleler yazmaktadir.

Posta adresi: C Çatalhüyük Munise Lütfi Onat İlkokulu, Çatalhüyük Mah. Alayköşkü Sk. No:5 Karatay / Konya Tel (İş):

GSM: $+903323596665$ +905065425507

Eposta:

URL: saygihali183@gmail.com http:// 